\title{
Trisomy 8 mosaicism in the placenta: a Danish cohort study of 37 cases and a literature review
}

\author{
Simon Horsholt Thomsen ${ }^{1}$, Ida Charlotte Bay Lund ${ }^{1}$, Christina Fagerberg ${ }^{2}$, Iben Bache ${ }^{3}$, \\ Naja Becher ${ }^{1}$, and Ida Vogel ${ }^{1}$ \\ ${ }^{1}$ Aarhus University Hospital \\ ${ }^{2}$ Odense University Hospital \\ ${ }^{3}$ University of Copenhagen
}

April 28, 2020

\begin{abstract}
Objective: To evaluate the risk of fetal involvement when trisomy 8 mosaicism (T8M) is detected in chorionic villus samples (CVS). Design: A retrospective descriptive study of registered cases in Denmark and a systematic literature review. Setting: Cases of T8M in CVS registered in Denmark between January 1983 and March 2019 and published literature until March 2019. Sample: A total of 37 registered pregnancies in Denmark and 60 published cases. Methods: Registered pregnancies with T8M in CVS were identified through a database search. Published cases of T8M were found through a systematic literature search and backward snowballing. Pregnancies with T8M in CVS and no additional numerical chromosomal aberrations were included. Main outcome measures: Fetal involvement defined as T8M in amniotic fluid (AF) or fetal tissue. Results: T8M detected in a CVS was associated with fetal involvement in 18 out of 97 pregnancies (18.6\% [95\%CI: 11.4-27.7]). Eight out of 70 (11.4\% [95\%CI: 5.1-21.3]) interpreted prenatally to be confined placental mosaicism (CPM) were found to be true fetal mosaicisms (TFM). Conclusion: T8M detected in CVS poses a significant risk of fetal involvement, and examination of AF and/or fetal tissue should be offered. However, a normal result of AF still has a considerable residual risk of fetal involvement. Genetic counselling at an early gestational age is essential, and follow-up ultrasonography should be performed to predict fetal involvement if possible. Funding: Ida Vogel is funded by a research grant from the Novo Nordic Foundation: NNF16OC0018772 Keyword: Trisomy, mosaicism, prenatal
\end{abstract}

\section{Tweetable abstract}

Trisomy 8 mosaicism in chorionic villi was associated with fetal involvement in 18 out of 97 pregnancies.

\section{Introduction}

Chromosomal mosaicism is characterized by the presence of two or more different cell lines in the same individual, and detected in $0.3 \%$ of amniotic fluid samples (AF) and more than $2 \%$ of chorionic villus samples (CVS) ${ }^{1}$. Trisomy 8 mosaicism (T8M) is a viable condition with a prevalence between 1:25,000 and 1:50,000. Non-mosaic trisomy 8 is nonviable and usually of meiotic origin ${ }^{2}$.

T8M is presumed to be the result of postzygotic non-disjunction ${ }^{2,3}$, and hence the trisomic cells are not evenly distributed in all cells causing different phenotypic anomalies. The most common clinical features of T8M are moderate intellectual disability, dysmorphic facial features, camptodactyly, deep plantar and palmar furrows, cardiac and renal anomalies, spinal deformities and agenesis of the corpus callosum ${ }^{3,4}$. However, the phenotypic spectrum is wide as T8M can also be found in healthy individuals with normal intelligence $^{5}$. No studies have yet reported an association between the frequency of trisomic cells and phenotypic outcome. Thus, it is difficult to establish a definite prognosis based on tissue analysis ${ }^{4}$. In 1996, 
Wolstenholme ${ }^{6}$ suggested a non-random distribution of aneuploid cells between the different extraembryonic cell lineages for trisomy 2, 3 and 8 . Thus, prenatally detected T8M is particularly challenging to handle in both the design of the genetic follow-up as well as in genetic counselling, as mosaicism confined to the placenta (confined placental mosaicism, CPM) interpreted prenatally may involve the fetus (true fetal mosaicism, TFM).

Large studies are lacking investigating the risk of fetal involvement in detection of T8M in a CVS. The objective of this study was to evaluate the risk of fetal involvement in a nationwide Danish cohort of 37 pregnancies with T8M detected in CVS along with a review of 60 published cases.

\section{Methods}

\section{The nationwide cohort}

We performed a retrospective, descriptive study using the Danish Cytogenetic Central Registry (DCCR), which contains prospectively registered data on all cytogenetic analyses performed in Denmark since $1960^{7}$. The first CVSs were registered in $1983^{8}$. We searched for pregnancies with T8M detected prenatally and registered between January 1983 and March 2019. These cases were crosschecked in the DCCR to identify any corresponding follow-up analyses in the same pregnancies. Non-mosaic pregnancies and pregnancies with other additional chromosomal numerical aberrations were excluded. We also searched for cases of T8M detected postnatally with a normal karyotype in prenatal examinations.

Live-born children without a follow-up blood or tissue analysis were presumed to be phenotypically normal at birth and therefore to have a normal karyotype or a very high likelihood hereof. Cases with missing result of CVS were excluded from the main results but are presented in Table S1 and S2.

\section{The Danish National Prenatal Screening Program}

Between 1978 and 2003, prenatal diagnostics was offered in Denmark to pregnant women above the age of 34 and to women with a family history of chromosomal abnormalities. Since 2004, invasive prenatal diagnostics have been offered if the combined first trimester screening (cFTS) estimates the risk of trisomy 21 to be above 1:300 or the risk of trisomy 13 or trisomy 18 to be higher than 1:150. cFTS is based on maternal age, nuchal translucency and serum concentrations of pregnancy associated plasma protein A (PAPP-A) and free $\beta$-hCG. $)^{9-11}$. The cFTS is free of charge and almost all $(97 \%)$ pregnant women in Denmark participate in the screening program ${ }^{11}$.

In Denmark, most CVSs are performed based on a high risk according to cFTS, while AC is mainly performed because of abnormal findings in $2^{\text {nd }}$ trimester ultrasonography. In 2018, around 2800 CVSs and 1400 ACs were performed in Denmark ${ }^{8,11}$.

This study was approved by the DCCR. As this was a register-based study approval from the Central Denmark Region Committee on Health Research Ethics was not required ${ }^{12}$. Data were registered in accordance with local guidelines ${ }^{13}$.

\section{Literature review}

A literature review was conducted by a systematic search in PubMed and backward snowballing ${ }^{14}$.

The systematic search in PubMed was conducted using the search terms "Chromosome 8, mosaic trisomy" [Supplementary Concept], "Mosaicism" [MeSH], "Prenatal Diagnosis" [MeSH], "Chromosome 8, trisomy" [Supplementary Concept], "Chromosomes, Human, Pair 8" [MeSH], "Pregnancy" [MeSH] and a free text search using the terms "trisomy 8", "trisomy eight", "warkany syndrom*", "mosaic", "prenatal" and "pregnancy outcome". The search identified 149 studies. After title and abstract screening, 77 studies were excluded; after full text review, a further 45 studies were excluded. A total of 27 studies were thus included for data analysis.

Reading through the references of the included studies (backward snowballing), we identified 118 articles of which 28 had already been found in the PubMed search. The remaining 90 articles were full text reviewed as 
they had been mentioned by other articles to be relevant for this investigation; title and abstract screening was thus skipped. After full text review, 69 studies were excluded and 21 studies were additionally included for data analysis.

Thus, a total of 48 studies were included presenting a total of 109 cases. Twenty of the 48 studies, representing 49 cases, did not contain information on CVS and were excluded (Table S1 and S2).

We classified the remaining 97 cases from the DCCR and published literature as either confined placental mosaicism (CPM) or true fetal mosaicism (TFM). We defined CPM as T8M detected in CVS and not detected in subsequent analysis of AF or fetal tissue. TFM was defined as T8M detected in AF or fetal tissue (fetal blood, umbilical cord blood or skin biopsy).

Core outcome sets (COS)

No COS was used when designing our study as a relevant COS does not exist.

Patient and public involvement

Patients were not involved in our study as it was based on registered data and published literature.

Funding

Professor in fetal diagnostics, Ida Vogel, is funded by a research grant from the Novo Nordic Foundation: NNF16OC0018772.

\section{Results}

A total of 61 pregnancies with trisomy 8 detected prenatally were identified in the Danish Cytogenetic Central Registry. Eight non-mosaic cases and six cases with additional chromosomal numerical aberrations were subsequently removed resulting in 47 pregnancies with T8M. Ten of these did not have any results from CVS and were thus not included in the risk estimated below (but listed in Table S1 and S2). We also found two cases of T8M diagnosed postnatally with a normal karyotype in AF. These two cases are also presented in Table S2.

In total, 97 cases of T8M detected in CVS are presented in Table 1. Thirty-seven cases are new cases from the DCCR, and 60 cases are from previously published articles and case reports; 72 cases could be classified as CPM, 18 cases as TFM and seven could not be classified as only a CVS result was available.

Of the 97 cases of T8M detected in CVS, 90 had a follow-up analysis on either AF or fetal tissue and 24 cases underwent both analyses (Fig. 1). In 11 cases results from AF and fetal tissue were discordant (3 had an abnormal result on AF but a normal result in fetal tissue, 8 had a normal result on AF but an abnormal result in fetal tissue).

In total, 18 of the 97 pregnancies with T8M detected in CVS (18.6\% [95\%CI: 11.4-27.7]) were confirmed by either AF or fetal tissue analysis (Fig. 1). Eight of the cases confirmed in fetal tissue analysis had AF examined with a normal result (false negative). Thus, these eight cases (case no. 18, 27, 46, 58, 59, 60, 61 and 79$)$ out of 70 (11.4\% [95\%CI: 5.1-21.3]) cases of apparent CPM were in fact TFM.

If the indication for invasive sampling was abnormal findings on ultrasonography, we found that a CVS with T8M was confirmed in fetal tissue in two out of three pregnancies. If the indication was increased risk after cFTS, then three out of 13 pregnancies had fetal involvement.

In Table S1, cases of T8M first detected in AF are presented. Eighteen out of 49 (36.7\% [95\%CI: 23.4-51.7]) of these cases were also confirmed in fetal tissue analysis; 13 were not confirmed in fetal tissue and 18 did not undergo fetal tissue analysis.

Table S2 presents cases of T8M first detected in fetal tissue. Eight out of these 12 cases had a previous amniocentesis with a normal result. These cases are not presented in Fig. 1. 
Of the 109 published cases, 80 reported phenotypic outcomes; of these, 58 were reported as having a normal phenotype. Nineteen cases had a follow-up period of $>1$ year $^{3,15-19}$; the rest only reported the phenotype at the time of birth. The 22 abnormal outcomes reported included heart malformations (atrial and ventricular septal defects), intrauterine growth retardation, club foot, clinodactyly, renal malformations, facial dysmorphisms, hernias, meningomyelocele, agenesis of the corpus callosum, deep palmar and plantar furrows and pulmonary hypertension.

\section{Discussion}

\section{Main findings}

Our study showed that a CVS with T8M demonstrated subsequent fetal involvement in 18\% (95\%CI: 11.427.7) of cases and is otherwise confined to the placenta. In 11\% (95\% CI: 5.1-21.3) T8M was, nevertheless, detected in fetal tissue after an apparently normal result in AF, thus representing a false negative result. Compared to other trisomic mosaicisms diagnosed in a CVS, these numbers are high ${ }^{20}$. T8M in a CVS thus poses a significant risk of fetal involvement, and even a normal result of a follow-up AF leaves a considerable residual risk for TFM.

\section{Strengths and limitations}

The major strength of our study is that we have included all cases of T8M detected prenatally in Denmark since CVS was implemented (initial result from 1983). All cases are expected to be registered in the DCCR through exhaustive reporting of high quality data ${ }^{21}$. This is supplemented by a high participation rate (97\%) in the cFTS and a high invasive rate ${ }^{11}$. Also, we conducted a thorough and systematic search of published literature. All articles were thoroughly reviewed to identify cases of T8M, and we looked through the reference lists of studies found in the initial search resulting in more cases.

One of the limitations of our study is a universal but significant weakness concerning the probable ascertainment bias towards the most severe cases where a CVS with T8M is confirmed by AF or results in an abnormal pregnancy outcome. This ascertainment bias will likely result in an overestimation of the risk of detecting T8M in the fetus after detecting T8M in CVS. However, ascertainment bias did not affect the data from the 37 cases in our nationwide cohort.

\section{Interpretation}

Some studies have hypothesized that trisomic AF cells could have a growth disadvantage compared to euploid cell lines ${ }^{3,22,23}$. This could explain why culture and subsequent karyotyping failed to detect T8M in $11 \%$ with an apparently normal amniocentesis result (Table 1).

Previously, there have been reported cases of uncultured cells where chromosomal microarray (CMA) was unable to detect low-grade mosaicism ${ }^{24}, 25$. Specifically, in two cases where CMA on uncultured amniocytes missed T8M detected in cultured amniocytes ${ }^{23,}{ }^{26}$. However, a recent study has demonstrated that CMA overall detects more mosaic cases than conventional karyotyping ${ }^{20}$. Using CMA on DNA from uncultured cells may eliminate a possible selective growth disadvantage of trisomic cells and pseudomosaicism in both chorionic villus biopsies and AF cells and is usually performed on a larger tissue mass than karyotyping. In Denmark, CMA performed on DNA extracted from uncultured, un-trypsinized chorionic villus cells is now the standard method ${ }^{27}$.

In our literature search and in the DCCR we revealed a total of 49 cases of T8M diagnosed in AF without a prior CVS (Table S1). In these cases, only 17 out of 49 (34.7\% [95\%CI: 21.7-49.6]) cases of T8M in AF were subsequently confirmed in fetal tissue. This was also evident for only four out of eight cases in Table 1. Thus, AF demonstrating T8M will not always be confirmed in the fetus or child. This may again be due to uneven distribution of a mitotic error in the individual cell lines examined ${ }^{6}$ and our study contains several examples of discordance in karyotype between e.g. blood and skin. In $11 \%$ of the cases initially interpreted as CPM there was involvement of the fetus. This conclusion is also demonstrated in Table S2, where eight out of 12 cases of T8M, not detected prenatally prior to the analyses of fetal tissue, had a previous result 
of AF showing a normal karyotype: again, a false negative result. Similar findings have previously been published $^{3,15-17,28-32}$.

In the published literature (both the cases presented in Table 1 and in Table S1 and S2), 80 cases included reports of the phenotypic outcome. However, many of the cases were not followed up postnatally in terms of growth and neurologic development. Only 19 cases had a follow-up period of one year or more ${ }^{3,15-19}$. While many of the traits in the T8M syndrome are visible at birth (deep palmar and plantar furrows, facial dysmorphisms, contractures of fingers and toes and spinal deformities ${ }^{3,4}$ ), some can only be recognized by extensive examination of internal organs (agenesis of the corpus callosum, cardiac and renal malformations ${ }^{16}$ ) and some can only be recognized as the child develops (intellectual disability and cognitive impairment ${ }^{3,4}$ ). More than half of the cases in the literature including phenotypic outcome, reported a normal phenotype at birth. This is a high proportion and could show that many of the phenotypic abnormalities in the T8M syndrome are not visible at birth. We suggest that future studies and case reports aim for a longer follow-up period to give a more accurate prognosis.

Our data showed that if abnormal findings on ultrasonography was the indication for invasive sampling, two out of three cases had fetal involvement. Obviously, a CVS result with T8M following an indication of abnormal ultrasonography has a higher probability of fetal involvement. However, some of the features of T8M cannot always be identified by ultrasonography and a normal ultrasound examination does therefore not exclude fetal involvement ${ }^{18}$. Wolstenholme ${ }^{6}$ hypothesized that in cases of T8M, it may be more difficult to predict fetal involvement based on the CVS result compared to placental mosaicism for trisomy of other chromosomes; our results confirm this enigma.

\section{Conclusion}

We have found that the detection of T8M in CVS is confirmed in AF or in the fetus proper in 18\%. Further, the prognosis after detection of true fetal $\mathrm{T} 8 \mathrm{M}$ is unclear and can cover a range from a normal pregnancy outcome to a severely affected child ${ }^{3,16}$. This makes counselling of pregnant couples very difficult. Based on the data presented here, examination of AF may additionally miss TFM in 11\%. Counselling must be performed at an early gestational age as some couples may choose to terminate the pregnancy before AF can be formed due to the particular uncertainty and potential severity of the T8M diagnosis compared to most other placental mosaicisms ${ }^{32,33}$. To support the genetic diagnosis, a certified fetal medicine expert could perform an ultrasound scan to detect possible additional findings. Although not all phenotypic features of T8M are visible by ultrasonography, fetal malformations will indicate fetal involvement thus reducing the uncertainty for the couple. Taken together, the handling of T8M is challenging, and the majority of couples still have normal, healthy children despite detecting T8M in CVS.

\section{Acknowledgements:}

The authors would like to thank the daily manager of the Danish Cytogenetic Central Registry, Jan Hansen, for searching the database.

\section{Disclosure of interests:}

All authors have nothing to declare.

\section{Contribution to authorship:}

SHT and IV concepted and designed this study and acquired the data for a first analysis and interpretation as well as made the first draft of the article.

ICBL contributed to the design of this study.

ICBL, CF, IB and NB contributed to interpretation of data and critical revision of the article for intellectual content.

All authors approved of the version of the article to be published and are accountable for all aspects of the work. 


\section{Details of ethics approval}

As this was a register-based study, approval from the Central Denmark Region Committee on Health Research Ethics was not required ${ }^{12}$. Data were registered in accordance with local guidelines ${ }^{13}$. This study was approved by the DCCR.

\section{Funding}

Professor in fetal diagnostics, Ida Vogel is funded by a research grant from the Novo Nordic Foundation: NNF16OC0018772.

\section{References}

1. Chromosomal mosaicism - prenatal. In: Firth HV, Hurst JA, Hall JG, editors. Oxford desk reference: clinical genetics. Oxford: Oxford University Press; 2005. p. 516.

2. Webb AL, Wolstenholme J, Evans J, Macphail S, Goodship J. Prenatal diagnosis of mosaic trisomy 8 with investigations of the extent and origin of trisomic cells. Prenatal diagnosis. 1998 Jul;18(7):737-41.

3. Cassina M, Calo A, Salviati L, Alghisi A, Montaldi A, Clementi M. Prenatal detection of trisomy 8 mosaicism: Pregnancy outcome and follow up of a series of 17 consecutive cases. European journal of obstetrics, gynecology, and reproductive biology. 2018 Feb;221:23-7.

4. Trisomy 8 mosaicism. In: Firth HV, Hurst JA, Hall JG, editors. Oxford desk reference : clinical genetics. Oxford: Oxford University Press; 2005. p. 530.

5. Mercier S, Bresson JL. Analysis of chromosomal equipment in spermatozoa of a $46, \mathrm{XY} / 47, \mathrm{XY} /+8$ male by means of multicolour fluorescent in situ hybridization: confirmation of a mosaicism and evaluation of risk for offspring. Human genetics. 1997 Jan;99(1):42-6.

6. Wolstenholme J. Confined placental mosaicism for trisomies 2, 3, 7, 8, 9, 16, and 22: their incidence, likely origins, and mechanisms for cell lineage compartmentalization. Prenatal diagnosis. 1996 Jun;16(6):511-24.

7. Danish Cytogenetic Central Registry. DCCR's historie. 2019 [cited 2020 Jan 22]; Available from: https://www.auh.dk/siteassets/afdelinger/klinisk-genetisk-afdeling/dccr/pdf/historie_okt2019.pdf

8. Danish Cytogenetic Central Registry. Antal prænatale undersøgelser efter Amnion og CVS 1970-2018. 2019 [cited 2020 Jan 22]; Available from: https://www.auh.dk/siteassets/afdelinger/klinisk-genetisk-afdeling/dccr/pdf/pnam-cvs_1970-2018.pdf

9. Ekelund CK, Petersen OB, Skibsted L, Kjaergaard S, Vogel I, Tabor A. First-trimester screening for trisomy 21 in Denmark: implications for detection and birth rates of trisomy 18 and trisomy 13. Ultrasound in obstetrics \& gynecology : the official journal of the International Society of Ultrasound in Obstetrics and Gynecology. 2011 Aug;38(2):140-4.

10. Lou S, Petersen OB, Jorgensen FS, Lund ICB, Kjaergaard S, Vogel I. National screening guidelines and developments in prenatal diagnoses and live births of Down syndrome in 1973-2016 in Denmark. Acta Obstet Gynecol Scand. 2018 Feb;97(2):195-203.

11. Sundhedsstyrelsen. Retningslinjer for fosterdiagnostik - prænatal information, risikovurdering, rådgivning og diagnostik. 2017 January 21st, 2020 [cited 2020 Jan 21]; Available from: https://www.sst.dk/da/sundhedog-livsstil/graviditet-og-foedsel/ /media/DF9E4D6167154966800B7ACC8B7F2B59.ashx

12. National Committee on Health Research Ethics. What to notify? [cited 20202020 Mar 10]; Available from: http://en.nvk.dk/how-to-notify/what-to-notify

13. Standarder for ansvarlig forskningspraksis ved Health. [cited 2020 10-03-20]; Available from: https://health.medarbejdere.a for_ansvarlig_forskningspraksis_Health_26.9.2019.pdf 
14. Wohlin C. Guidelines for snowballing in systematic literature studies and a replication in software engineering. Proceedings of the 18th International Conference on Evaluation and Assessment in Software Engineering. London, England, United Kingdom: Association for Computing Machinery; 2014. p. Article 38.

15. Klein J, Graham JM, Jr., Platt LD, Schreck R. Trisomy 8 mosaicism in chorionic villus sampling: case report and counselling issues. Prenatal diagnosis. 1994 Jun;14(6):451-4.

16. Miller K, Arslan-Kirchner A, Schulze B, Dudel-Neujahr A, Morlot M, Burck U, et al. Mosaicism in trisomy 8: phenotype differences according to tissular repartition of normal and trisomic clones. Annales de genetique. 1997;40(3):181-4.

17. Rodriguez MJ, Moreno-Cid M, Rubio A, Pastor C, De Leon J, Puerto B, et al. Trisomy 8 mosaicism a controversial prenatal diagnosis. Journal of obstetrics and gynaecology : the journal of the Institute of Obstetrics and Gynaecology. 2013 Feb;33(2):204-5.

18. Saks E, McCoy MC, Damron J, Kelly TE. Confined placental mosaicism for trisomy 8 and intra-uterine growth retardation. Prenatal diagnosis. 1998 Nov;18(11):1202-4.

19. Camurri L, Chiesi A. A three-year follow-up on a child with low level trisomy 8 mosaicism which was diagnosed prenatally. Prenatal diagnosis. 1991 Jan;11(1):59-62.

20. Lund ICB, Becher N, Christensen R, Petersen OB, Steffensen EH, Vestergaard EM, et al. Prevalence of mosaicism in uncultured chorionic villus samples after chromosomal microarray and clinical outcome in pregnancies affected by confined placental mosaicism. Prenatal diagnosis. 2019 Nov 26.

21. Nguyen-Nielsen M, Svensson E, Vogel I, Ehrenstein V, Sunde L. Existing data sources for clinical epidemiology: Danish registries for studies of medical genetic diseases. Clin Epidemiol. 2013;5:249-62.

22. Hulley BJ, Hummel M, Cook LL, Boyd BK, Wenger SL. Trisomy 8 mosaicism: selective growth advantage of normal cells vs. growth disadvantage of trisomy 8 cells. American journal of medical genetics Part A. 2003 Jan 15;116a(2):144-6.

23. Chen CP, Su YN, Chern SR, Chen YT, Su JW, Pan CW, et al. Prenatal diagnosis of trisomy 8 mosaicism. Taiwanese journal of obstetrics \& gynecology. 2012 Dec;51(4):666-8.

24. Ballif BC, Rorem EA, Sundin K, Lincicum M, Gaskin S, Coppinger J, et al. Detection of low-level mosaicism by array CGH in routine diagnostic specimens. American journal of medical genetics Part A. 2006 Dec 15;140(24):2757-67.

25. Shaffer LG, Kashork CD, Saleki R, Rorem E, Sundin K, Ballif BC, et al. Targeted genomic microarray analysis for identification of chromosome abnormalities in 1500 consecutive clinical cases. The Journal of pediatrics. $2006 \mathrm{Jul} ; 149(1): 98-102$.

26. Chen CP, Chen M, Pan YJ, Su YN, Chern SR, Tsai FJ, et al. Prenatal diagnosis of mosaic trisomy 8: clinical report and literature review. Taiwanese journal of obstetrics \& gynecology. 2011 Sep;50(3):331-8

27. Vogel I, Petersen OB, Christensen R, Hyett J, Lou S, Vestergaard EM. Chromosomal microarray as primary diagnostic genomic tool for pregnancies at increased risk within a population-based combined firsttrimester screening program. Ultrasound in obstetrics \& gynecology : the official journal of the International Society of Ultrasound in Obstetrics and Gynecology. 2018 Apr;51(4):480-6.

28. Hanna JS, Neu RL, Barton JR. Difficulties in prenatal detection of mosaic trisomy 8. Prenatal diagnosis. 1995 Dec;15(12):1196-7.

29. de Pater JM, Schuring-Blom GH, Nieste-Otter MA, van Nesselrooij B, Kapitein B, Christiaens GC, et al. Trisomy 8 in chorionic villi-unpredictable results in follow-up. Prenatal diagnosis. 2000 May;20(5):435-7.

30. Schneider M, Klein-Vogler U, Tomiuk J, Schliephacke M, Leipoldt M, Enders H. Pitfall: amniocentesis fails to detect mosaic trisomy 8 in a male newborn. Prenatal diagnosis. 1994 Jul;14(7):651-2. 
31. Southgate WM, Wagner CL, Shields SM, Cantu ES, Pai GS. Mosaic trisomy 8: a cautionary note regarding missed antenatal diagnosis. Journal of perinatology : official journal of the California Perinatal Association. 1998 Jan-Feb;18(1):78-80.

32. Hahnemann JMV, L. O. . European collaborative research on mosaicism in CVS (EUCROMIC) - fetal and extrafetal cell lineages in 192 gestations with CVS mosaicism involving single autosomal trisomy. American journal of medical genetics. 1997;70(2):179-87.

33. Grati FR. Chromosomal Mosaicism in Human Feto-Placental Development: Implications for Prenatal Diagnosis. J Clin Med. 2014 Jul 24;3(3):809-37.

34. Campbell S, Mavrides E, Prefumo F, Presti F, Carvalho JS. Prenatal diagnosis of mosaic trisomy 8 in a fetus with normal nuchal translucency thickness and reversed end-diastolic ductus venosus flow. Ultrasound in obstetrics \& gynecology : the official journal of the International Society of Ultrasound in Obstetrics and Gynecology. 2001 Apr;17(4):341-3.

35. Guichet A, Briault S, Toutain A, Paillet C, Descamps P, Pierre F, et al. Prenatal diagnosis of trisomy 8 mosaicism in CVS after abnormal ultrasound findings at 12 weeks. Prenatal diagnosis. 1995 Aug;15(8):769-72.

36. van Haelst MM, Van Opstal D, Lindhout D, Los FJ. Management of prenatally detected trisomy 8 mosaicism. Prenatal diagnosis. 2001 Dec;21(12):1075-8.

37. Karadima G, Bugge M, Nicolaidis P, Vassilopoulos D, Avramopoulos D, Grigoriadou M, et al. Origin of nondisjunction in trisomy 8 and trisomy 8 mosaicism. European journal of human genetics : EJHG. 1998 Sep-Oct;6(5):432-8.

38. Schubert R, Raff R, Schwanitz G. Molecular-cytogenetic investigations of ten term placentae in cases of prenatally diagnosed mosaicism. Prenatal diagnosis. 1996 Oct;16(10):907-13.

39. Turchetti D, Pompilii E, Magrini E, Bonasoni MP, Pittalis MC, Segata M, et al. Persistence of a monosomic cell line in a fetus with mosaic trisomy 8. American journal of medical genetics Part A. 2011 Nov;155a(11):2791-4.

40. Torring N, Petersen OB, Becher N, Vogel I, Uldbjerg N. First trimester screening for other trisomies than trisomy 21, 18, and 13. Prenatal diagnosis. 2015 Jun;35(6):612-9.

41. Wang BB, Rubin CH, Williams J, 3rd. Mosaicism in chorionic villus sampling: an analysis of incidence and chromosomes involved in 2612 consecutive cases. Prenatal diagnosis. 1993 Mar;13(3):179-90.

42. Cytogenetic analysis of chorionic villi for prenatal diagnosis: an ACC collaborative study of U.K. data. Association of Clinical Cytogeneticists Working Party on Chorionic Villi in Prenatal Diagnosis. Prenatal diagnosis. 1994 May;14(5):363-79.

43. Green JE, Dorfmann A, Jones SL, Bender S, Patton L, Schulman JD. Chorionic villus sampling: experience with an initial 940 cases. Obstetrics and gynecology. 1988 Feb;71(2):208-12.

44. Johnson A, Wapner RJ, Davis GH, Jackson LG. Mosaicism in chorionic villus sampling: an association with poor perinatal outcome. Obstetrics and gynecology. 1990 Apr;75(4):573-7.

45. Kalousek DK, Howard-Peebles PN, Olson SB, Barrett IJ, Dorfmann A, Black SH, et al. Confirmation of CVS mosaicism in term placentae and high frequency of intrauterine growth retardation association with confined placental mosaicism. Prenatal diagnosis. 1991 Oct;11(10):743-50.

46. Ledbetter DH, Zachary JM, Simpson JL, Golbus MS, Pergament E, Jackson L, et al. Cytogenetic results from the U.S. Collaborative Study on CVS. Prenatal diagnosis. 1992 May;12(5):317-45.

47. Leschot NJ, Schuring-Blom GH, Van Prooijen-Knegt AC, Verjaal M, Hansson K, Wolf H, et al. The outcome of pregnancies with confined placental chromosome mosaicism in cytotrophoblast cells. Prenatal diagnosis. 1996 Aug;16(8):705-12. 
48. Robinson WP, Barrett IJ, Bernard L, Telenius A, Bernasconi F, Wilson RD, et al. Meiotic origin of trisomy in confined placental mosaicism is correlated with presence of fetal uniparental disomy, high levels of trisomy in trophoblast, and increased risk of fetal intrauterine growth restriction. American journal of human genetics. 1997 Apr;60(4):917-27.

49. Teshima IE, Kalousek DK, Vekemans MJ, Markovic V, Cox DM, Dallaire L, et al. Canadian multicenter randomized clinical trial of chorion villus sampling and amniocentesis. chromosome mosaicism in CVS and amniocentesis samples. Prenatal diagnosis. 1992 May;12(5):443-66.

50. Wolstenholme J, Rooney DE, Davison EV. Confined placental mosaicism, IUGR, and adverse pregnancy outcome: a controlled retrospective U.K. collaborative survey. Prenatal diagnosis. 1994 May;14(5):345-61.

51. Wang BT, Peng W, Cheng KT, Chiu SF, Ho W, Khan Y, et al. Chorionic villi sampling: laboratory experience with 4,000 consecutive cases. American journal of medical genetics. 1994 Dec 1;53(4):307-16.

52. Miny P, Hammer P, Gerlach B, Tercanli S, Horst J, Holzgreve W, et al. Mosaicism and accuracy of prenatal cytogenetic diagnoses after chorionic villus sampling and placental biopsies. Prenatal diagnosis. 1991 Aug;11(8):581-9.

53. Hogge WA, Schonberg SA, Golbus MS. Chorionic villus sampling: experience of the first 1000 cases. American journal of obstetrics and gynecology. 1986 Jun;154(6):1249-52.

\section{Table and figure list}

Table 1: Cases of trisomy 8 mosaicism detected after CVS. Cases 1-37 from DCCR, cases 38-97 from published literature.

Figure 1: Flowchart of trisomy 8 mosaicism cases

Table S1: Cases of trisomy 8 mosaicism detected after amniocentesis.

Table S2: Cases of trisomy 8 mosaicism first detected in fetal tissue.

\begin{tabular}{|c|c|c|c|c|c|c|c|c|c|}
\hline Case & GA & Indication & CVS* & CVS* & $\begin{array}{l}\text { Amniotic } \\
\text { fluid }\end{array}$ & Tissue & Tissue & Outcome & \\
\hline & & & & & & Fetal & $\begin{array}{l}\text { Post- } \\
\text { abortem } \\
/ \\
\text { post- } \\
\text { natal }\end{array}$ & & \\
\hline \multicolumn{9}{|l|}{ DCCR } & \\
\hline 1 & 10 & AMA & $46, \mathrm{XY} /$ & XY46\&XY & $\mathrm{Y}+8$ & - & - & TOP & \\
\hline 2 & 12 & AMA & $46, \mathrm{XX} /$ & XX468XX & $\mathrm{X} 468 \mathrm{XX}$ & - & - & $\begin{array}{l}\text { Live } \\
\text { born }\end{array}$ & \\
\hline 3 & 12 & AMA & $46, \mathrm{XX} /$ & XX468XX & $\mathrm{X} 468 \mathrm{XX} / 47, \mathrm{X}$ & $\mathrm{X}+8$ & - & TOP & \\
\hline 4 & 13 & AMA & $46, \mathrm{XX} /$ & XX468XX & $\mathrm{X} 468 \mathrm{XX}$ & - & - & $\begin{array}{l}\text { Live } \\
\text { born }\end{array}$ & \\
\hline 5 & 15 & AMA & $46, \mathrm{XX} /$ & XX468XX & $\mathrm{X} 468 \mathrm{XX}$ & - & - & $\begin{array}{l}\text { Live } \\
\text { born }\end{array}$ & \\
\hline 6 & 14 & NA & $46, \mathrm{XY}[$ & $47,6, \mathrm{XA} 8$ & $17,6, \mathrm{XA} 8[14]$ & $46, \mathrm{XY}^{\mathrm{ii}}$ & $46, \mathrm{XY}^{\mathrm{ii}}$ & $\begin{array}{l}\text { Live } \\
\text { born }\end{array}$ & \\
\hline 7 & 15 & AMA & $46, \mathrm{XX} /$ & XX468XX, & $\begin{array}{c}\text { X468XX, } \\
\operatorname{inv}(9)\end{array}$ & - & - & $\begin{array}{l}\text { Live } \\
\text { born }\end{array}$ & \\
\hline 8 & 10 & AMA & $46, \mathrm{XY}[$ & $47,16, X \times 8$ & $47, \mathrm{XY}+8[6]$ & $46, X Y^{\mathrm{ii}}$ & $46, \mathrm{XY}^{\mathrm{ii}}$ & TOP & \\
\hline
\end{tabular}




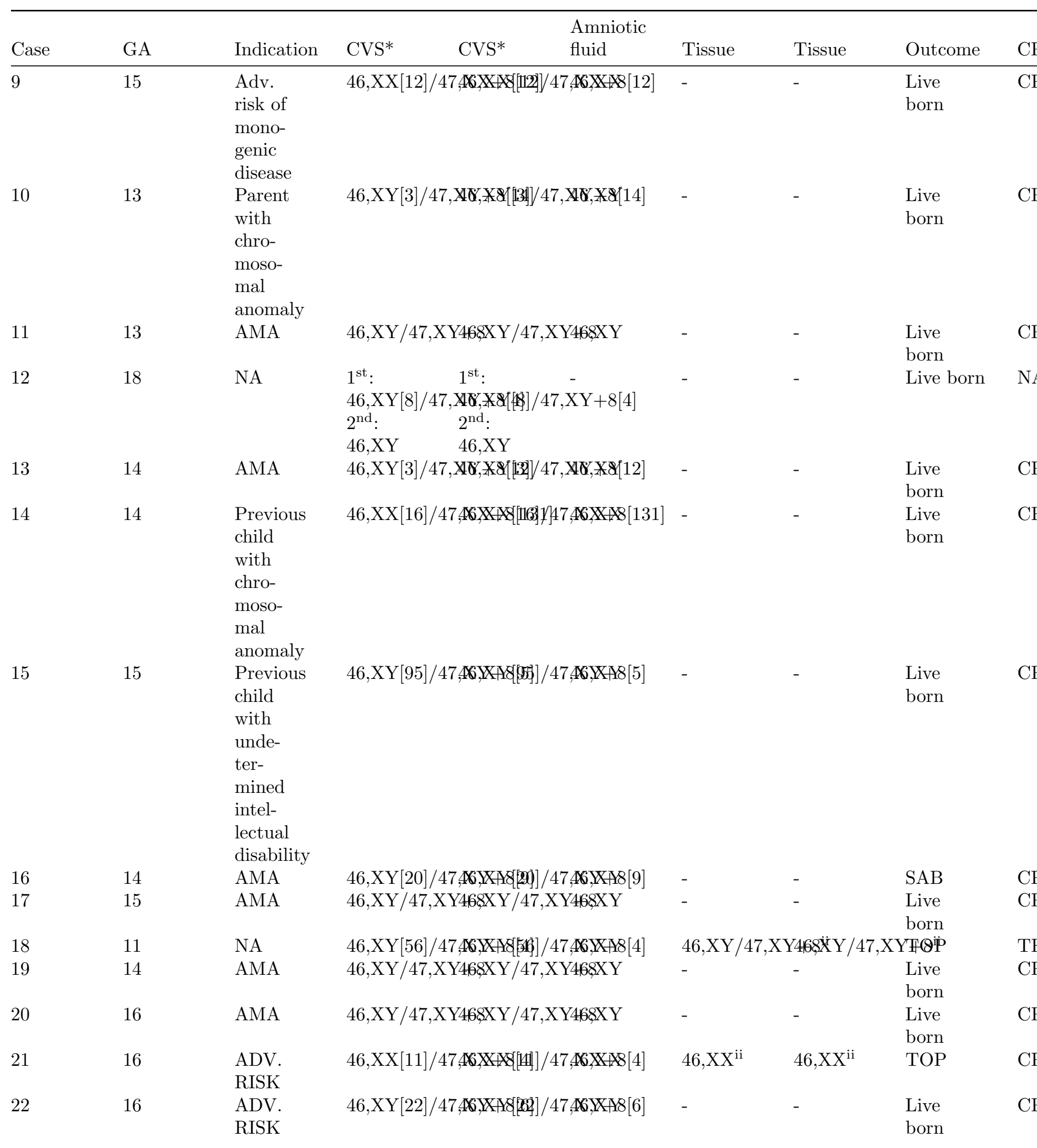




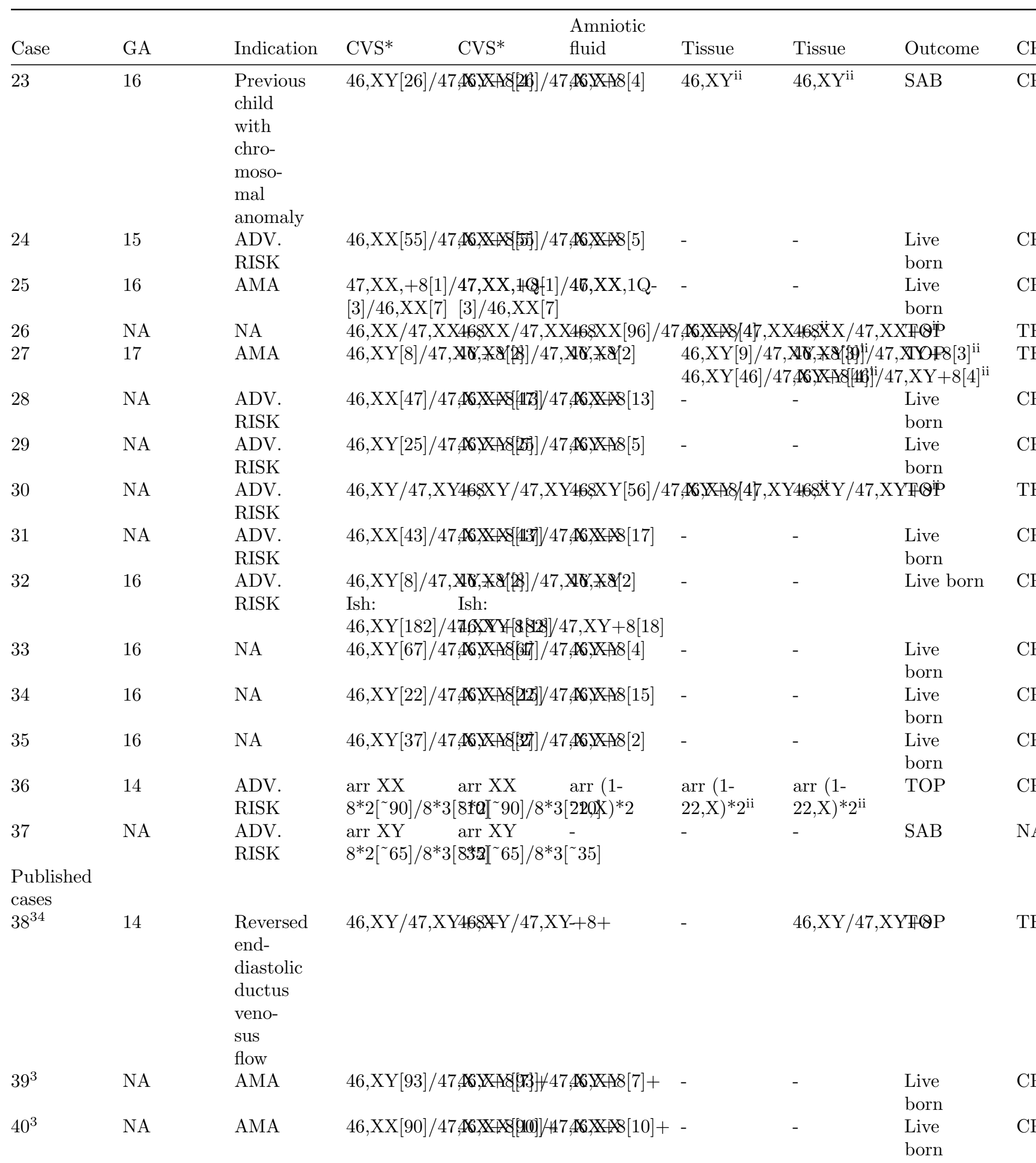




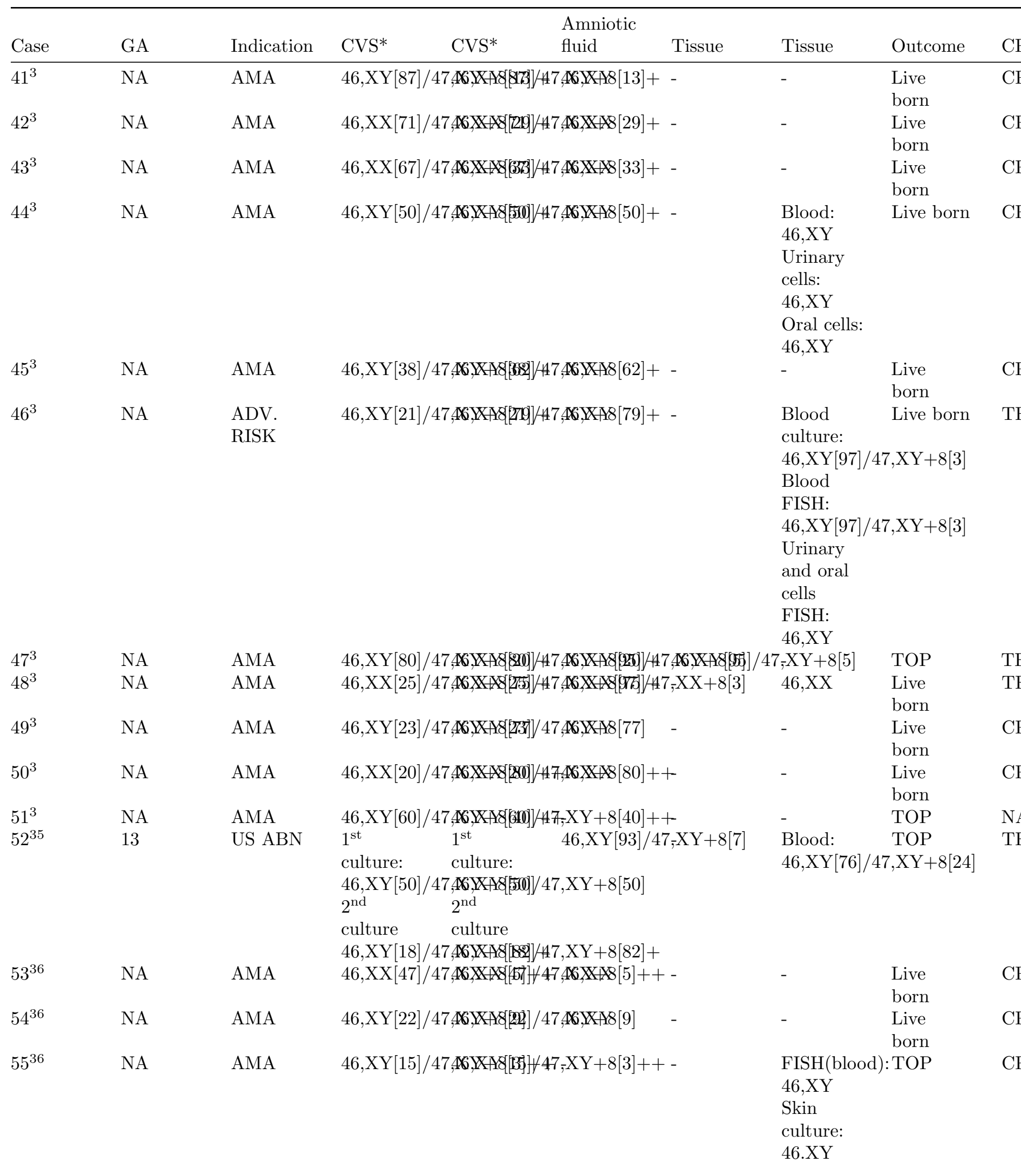




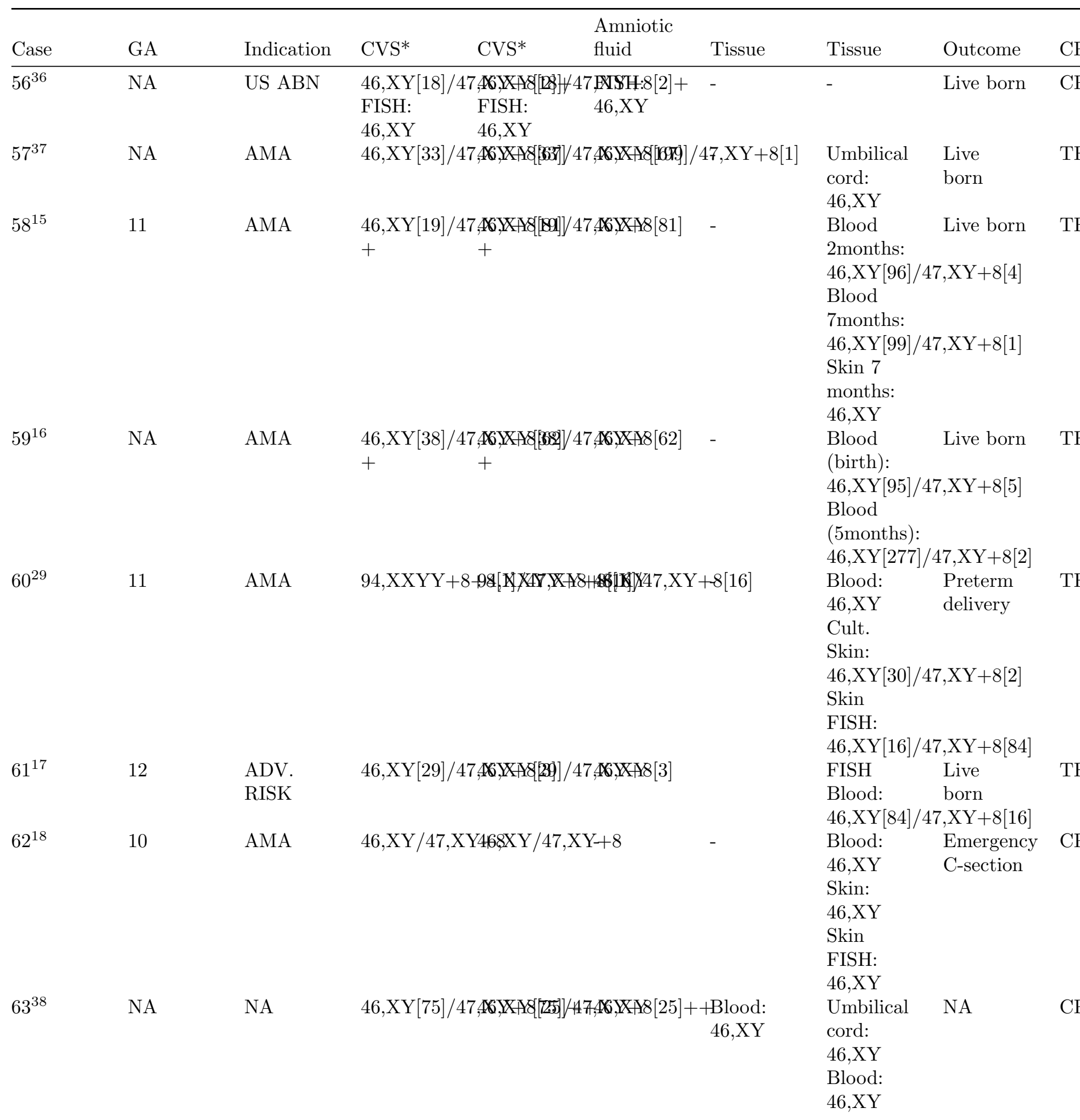




\begin{tabular}{|c|c|c|c|c|c|c|c|}
\hline Case & GA & Indication & $\begin{array}{l}\text { Amniotic } \\
\text { fluid }\end{array}$ & Tissue & Tissue & Outcome & $\mathrm{Cl}$ \\
\hline $64^{39}$ & 14 & US ABN & $46, \mathrm{XY}[53] / 47, \mathbf{1 6}, \mathrm{XX} 8[131]] / 47, \mathrm{XY}+8[11]+$ & - & $\begin{array}{l}\text { Umbilical } \\
\text { cord: } \\
\text { 46,XY } \\
\text { Skin: } \\
\text { 46,XY } \\
\text { FISH } \\
\text { Liver: } \\
\text { 45,XY- } \\
\text { 8[23]/46,X } \\
\text { FISH } \\
\text { Kidney: } \\
\text { 46,XY[57]/ } \\
\text { 8[43] }\end{array}$ & $\begin{array}{l}54] / 47, \mathrm{XY} \\
{[4, \mathrm{XY}-} \\
5\end{array}$ & \\
\hline $65^{40}$ & 12 & $\begin{array}{l}\text { ADV. } \\
\text { RISK }\end{array}$ & $46, X Y[5] / 47, X 8, X 8[59] \forall 47, X 8, X 8[5]++$ & - & - & NA & \\
\hline $66^{41}$ & NA & NA & 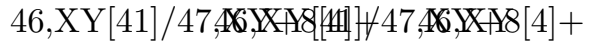 & - & - & NA & \\
\hline $67^{41}$ & NA & NA & $46, \mathrm{XY}[31] / 47, \mathbf{1 6}, \mathrm{XA} 8[311] / 47, \mathbb{6}, \mathrm{XA} 8[31]+$ & - & - & NA & \\
\hline $68^{41}$ & NA & NA & 46,XY[68]/47, $6, \mathrm{XA} 8[28] \forall 47, \mathbb{6}, \mathrm{XA8}[2]+$ & - & - & NA & \\
\hline $69^{42}$ & NA & NA & $46, \mathrm{XY}[60] / 47, \mathbb{6}, \mathrm{XA} 8[60] \forall 47, \mathrm{XY}+8[5]+$ & - & $46, \mathrm{XY}$ & TOP & \\
\hline $70^{42}$ & $\mathrm{NA}$ & NA & $46, \mathrm{XX}[22] / 47, \mathbb{1} \times \mathrm{XX8}[82] \forall 47, \mathbb{1} \times \mathrm{XX8}[8]+$ & - & $\begin{array}{l}\text { Blood: } \\
46, \mathrm{XX}\end{array}$ & $\begin{array}{l}\text { Live } \\
\text { born }\end{array}$ & \\
\hline $71^{43}$ & NA & AMA & $46, \mathrm{XN} / 47, \mathrm{XN} 468 \mathrm{XN} / 47, \mathrm{XN} 468 \mathrm{XN}$ & - & - & NA & \\
\hline $72^{32}$ & NA & NA & 46,XN/47,XN468XN/47,XN-8 & - & $46, \mathrm{XN}$ & NA & \\
\hline $73^{32}$ & NA & NA & $46, \mathrm{XN} / 47, \mathrm{XN} 468 \mathrm{XN} / 47, \mathrm{XN}+8$ & - & $46, \mathrm{XN}$ & NA & \\
\hline $74^{32}$ & NA & NA & $46, \mathrm{XN} / 47, \mathrm{XN} 468 \mathrm{XN} / 47, \mathrm{XN}+8$ & - & $46, \mathrm{XN}$ & NA & \\
\hline $75^{32}$ & NA & NA & 46,XN/47,XN468XN/47,XN-8 & - & $46, \mathrm{XN}$ & NA & \\
\hline $76^{32}$ & NA & NA & $46, \mathrm{XN} / 47, \mathrm{XN} 468 \mathrm{XN} / 47, \mathrm{XN}+8+$ & - & $46, \mathrm{XN}$ & NA & \\
\hline $77^{32}$ & NA & NA & $46, \mathrm{XN} / 47, \mathrm{XN} 468 \mathrm{XN} / 47, \mathrm{XN}+8+$ & - & $46, \mathrm{XN}$ & NA & \\
\hline $78^{32}$ & NA & NA & $46, \mathrm{XN} / 47, \mathrm{XN} 468 \mathrm{XN} / 47, \mathrm{XN} 468 \mathrm{XN}[97] / 47$ & $7, \mathrm{XN}+8[3]$ & $46, \mathrm{XN}$ & TOP & \\
\hline $79^{32}$ & NA & NA & $46, \mathrm{XN} / 47, \mathrm{XN} 468 \mathrm{XN} / 47, \mathrm{XN} 468 \mathrm{XN}$ & - & $46, \mathrm{XN}[95] /$ & $\begin{array}{l}\text { 7., } \\
\text { born }+8[5]\end{array}$ & \\
\hline $80^{44}$ & NA & NA & 46,XY/47,XY468XY /47,XY468XY & - & - & $\mathrm{SAB}$ & \\
\hline $81^{45}$ & NA & NA & 46,XN[40]/47,6,XA[[660]/47,46,XA8[60] & - & $\begin{array}{l}\text { Chord } \\
\text { blood: } \\
46, \mathrm{XN}\end{array}$ & NA & \\
\hline $82^{46}$ & NA & NA & $46, \mathrm{XN}[22] / 47, \mathbb{1}, \mathrm{XN} 8[24] / 47, \mathbb{6}, \mathrm{XNB}[7]$ & - & - & $\begin{array}{l}\text { Live } \\
\text { born }\end{array}$ & $\mathrm{Cl}$ \\
\hline $83^{46}$ & NA & NA & $46, \mathrm{XN}[20] / 47, \mathbb{1}, \mathrm{XA}[[2]] \forall 47, \mathbb{1}, \mathrm{XA}[2]+$ & - & - & $\begin{array}{l}\text { Live } \\
\text { born }\end{array}$ & $\mathrm{Cl}$ \\
\hline $84^{46}$ & NA & NA & 46,XN[4]/47,Xס, $\$ 64] \forall 4, X 0, X]+$ & - & - & $\begin{array}{l}\text { Live } \\
\text { born }\end{array}$ & $\mathrm{Cl}$ \\
\hline $85^{47}$ & $<14$ & NA & $46, \mathrm{XY}[7] / 47, \mathrm{X}, \mathrm{X} \$[8]] \forall 4, \mathrm{X} \mathbb{X} \mathbb{X}[8]++$ & - & - & $\begin{array}{l}\text { Live } \\
\text { born }\end{array}$ & $\mathrm{Cl}$ \\
\hline $86^{47}$ & $<14$ & NA & $46, \mathrm{XX}[2] / 47, \mathrm{X}, \mathrm{X}[64] 47, \mathrm{X}, \mathrm{X} 6]++$ & - & - & $\begin{array}{l}\text { Live } \\
\text { born }\end{array}$ & $\mathrm{Cl}$ \\
\hline $87^{47}$ & $<14$ & NA & $46, \mathrm{XX}[4] / 47, \mathrm{X}, \mathrm{X}[[14] / 47, \mathrm{X}, \mathrm{X}[12]++$ & - & - & $\begin{array}{l}\text { Live } \\
\text { born }\end{array}$ & \\
\hline $88^{47}$ & $<14$ & NA & 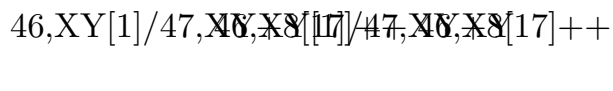 & - & - & $\begin{array}{l}\text { Live } \\
\text { born }\end{array}$ & \\
\hline
\end{tabular}




\begin{tabular}{|c|c|c|c|c|c|c|c|c|}
\hline Case & GA & Indication & CVS* & $\begin{array}{l}\text { Amniotic } \\
\text { fluid }\end{array}$ & Tissue & Tissue & Outcome & $\mathrm{Cl}$ \\
\hline $89^{47}$ & $<14$ & NA & $46, \mathrm{XX}[3] / 47, \mathrm{X}, \mathbb{X}$ & $\mathbb{X}, \mathbb{X}[13]++$ & - & - & $\begin{array}{l}\text { Live } \\
\text { born }\end{array}$ & $\mathrm{C}$ \\
\hline $90^{47}$ & $<14$ & NA & $46, \mathrm{XY}[13] / 47, \mathbb{6}, \mathrm{XX}$ & 7, $, 6, X 円 8[3]++$ & - & - & $\begin{array}{l}\text { Live } \\
\text { born }\end{array}$ & $\mathrm{C}$ \\
\hline $91^{48}$ & NA & AMA & $46, \mathrm{XN}[7] / 47, \mathrm{XD}, \mathrm{X}$ & $\mathrm{XN}+8[93]$ & - & - & $\begin{array}{l}\text { Live } \\
\text { born }\end{array}$ & $\mathrm{N}$ \\
\hline $92^{49}$ & NA & $\mathrm{AMA}$ & $46, \mathrm{XX}[10] / 47, \mathbb{X X}$ & $7 ; \mathrm{XX}+8[2]+$ & - & - & $\begin{array}{l}\text { Live } \\
\text { born }\end{array}$ & $\mathrm{N}$ \\
\hline $93^{50}$ & 10 & AMA & $46, \mathrm{XY}[20] / 47, \mathbf{W}, \mathrm{XX} 8$ & 7,\$6,XА1 $[4]+$ & $46, \mathrm{XY}$ & - & $\begin{array}{l}\text { Live } \\
\text { born }\end{array}$ & $\mathrm{C}$ \\
\hline $94^{51}$ & NA & NA & 46,XY \{76]/474X,X¥ & $74 \mathbb{X} \mathbb{X} ¥ 8[18]+$ & - & - & NA & $\mathrm{C}$ \\
\hline $95^{52}$ & NA & NA & $46, \mathrm{XY}[4] / 47, \mathrm{X} \mathbb{X}, \mathrm{X}$ & 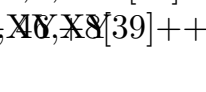 & - & - & $\begin{array}{l}\text { Live } \\
\text { born }\end{array}$ & \\
\hline $96^{52}$ & NA & NA & $46, \mathrm{XX}[5] / 47, \mathrm{X}, \mathrm{X}$ &, $\mathrm{XX}+8[4]+$ & - & - & $\begin{array}{l}\text { Live } \\
\text { born }\end{array}$ & $\mathrm{N}$ \\
\hline $97^{53}$ & NA & NA & $46, \mathrm{XY} / 47, \mathrm{XY} 468 \mathrm{XY}$ & Y468XY & - & - & NA & $\mathrm{C}$ \\
\hline
\end{tabular}

Table 1. Cases of trisomy 8 mosaicism detected after CVS. Cases 1-37 from DCCR, cases 38-97 from published literature.

CVS: chorion villus sample, AMA: advanced maternal age (>35), FISH: fluorescence in situ hybridization, NA : not available, ADV. RISK: advanced risk of chromosomal anomalies on prenatal screening, US ABN: abnormal findings on ultrasound, TOP: terminations of pregnancy, SAB: spontaneous abortion

*: Long term culture if nothing else is stated.

+: Short term culture performed with normal result.

++ : Short term culture.

: Short term culture. Long term culture performed with normal result.

ii: No information whether it is fetal tissue or post-abortem/postnatal tissue.

\begin{tabular}{|c|c|c|c|c|c|c|}
\hline Case & GA & Indication & $\begin{array}{l}\text { Amniotic } \\
\text { fluid }\end{array}$ & Tissue & Tissue & Outcome \\
\hline & & & & Fetal & \multicolumn{2}{|c|}{$\begin{array}{l}\text { Post- } \\
\text { abortem / } \\
\text { postnatal }\end{array}$} \\
\hline \multicolumn{7}{|l|}{ DCCR } \\
\hline 98 & 16 & AMA & \multicolumn{4}{|c|}{$46, \mathrm{XY} / 47, \mathrm{XY},+846, \mathrm{XY} / 47, \mathrm{XY}+8^{*} 46, \mathrm{XY} / 47, \mathrm{XY}+8^{*} \mathrm{TOP}$} \\
\hline 99 & 15 & ADV. RISK & \multicolumn{4}{|c|}{$46, \mathrm{XX}[51] / 47, \mathrm{XX} 48,\left[\mathrm{XOX} / 47, \mathrm{XX}+8^{*} 46, \mathrm{XX} / 47, \mathrm{XX}+8^{*} \mathrm{SAB}\right.$} \\
\hline 100 & 29 & US ABN. & $46, \mathrm{XX}[75]$ & $\mathrm{K}+8[25]$ & - & TOP \\
\hline 101 & NA & ADV. RISK & \multicolumn{4}{|c|}{ 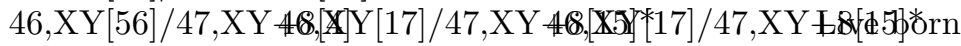 } \\
\hline 102 & 15 & ADV. RISK & \multicolumn{4}{|c|}{ 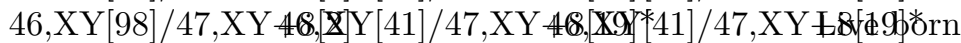 } \\
\hline 103 & 18 & ADV. RISK & $\begin{array}{l}\text { Arr XX } \\
8^{*} 2 / 8^{*} 3\end{array}$ & - & - & TOP \\
\hline $\begin{array}{l}104 \\
\text { Published } \\
\text { cases }\end{array}$ & 21 & US ABN. & $46, \mathrm{XY}[60]$ & $Y+8[2]$ & - & TOP \\
\hline
\end{tabular}




\begin{tabular}{|c|c|c|c|c|c|}
\hline Case & GA & Indication & $\begin{array}{l}\text { Amniotic } \\
\text { fluid }\end{array}$ & Tissue & Outcome \\
\hline $105^{28,29}$ & NA & $\begin{array}{l}\text { Previous child } \\
\text { with } \\
\text { congenital } \\
\text { malformation }\end{array}$ & $\begin{aligned}46, \mathrm{XX}[1] / 47, \mathrm{XX}+\mathrm{B} \notin \mathbb{Q} \mathrm{a}] \text { blood: } \\
46, \mathrm{XX} / 47, \mathrm{XX}+8\end{aligned}$ & $\begin{array}{l}\text { Blood: } \\
\text { 46,XX/47,XX+8 } \\
\text { Skin: } 46, \mathrm{XX}\end{array}$ & Live born \\
\hline $106^{2}$ & NA & ADV. RISK & $46, \mathrm{XX}[96] / 47, \mathrm{XX}+8[4]$ & $46, \mathrm{XX}$ & Live born \\
\hline $107^{2}$ & NA & AMA & $46, \mathrm{XX}[95] / 47, \mathrm{XX}+8[5]$ & - & Live born \\
\hline $108^{2}$ & NA & AMA & $46, \mathrm{XX}[95] / 47, \mathrm{XX}+8[5]$ & - & Live born \\
\hline $109^{30}$ & 16 & AMA & 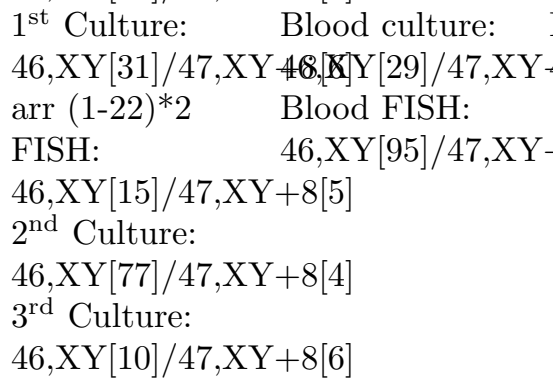 & $\begin{array}{l}\text { Blood culture: } \\
48,[\mathrm{X}] \mathrm{Y}[29] / 47, \mathrm{XY} \\
+8[5]\end{array}$ & $\begin{array}{l}\text { Preterm } \\
\text { \#8[ik]ery }\end{array}$ \\
\hline $110^{31}$ & 18 & AMA & $\begin{array}{l}1^{\text {st }} \text { culture: Blood culture: } \\
46, \mathrm{XX}[24] / 47, \mathrm{XX} 4 \mathbf{4},[\mathrm{X}] \mathrm{X} \\
\text { arr }(1-22, \mathrm{X})^{*} 2 \\
\text { FISH: } \\
\text { 46,XX }[80] / 47, \mathrm{XX}+8[20] \\
2^{\text {nd }} \text { Culture: } \\
\text { 46,XX FISH: } \\
\text { 46,XX }[32] / 47, \mathrm{XX}+8[6] \\
3^{\text {rd }} \text { Culture: } \\
46, \mathrm{XX}\end{array}$ & $\begin{array}{l}\text { Blood: } 46, \mathrm{XX} \\
\text { FISH(urinary): } \\
46, \mathrm{XX}[94] / 47, \mathrm{XY}\end{array}$ & $\begin{array}{l}\text { Live born } \\
+8[4]\end{array}$ \\
\hline $111^{4}$ & NA & $\mathrm{US} \mathrm{ABN}$ & $\begin{array}{l}46, \mathrm{XY}[32] / 47, \mathrm{XY}+8[1] \\
\text { FISH: } 46, \mathrm{XY}\end{array}$ & - & Live born \\
\hline $112^{4}$ & NA & AMA & $\begin{array}{l}1^{\text {st }}: \\
46, X X[10] / 47, X X+8[1] \\
1^{\text {st }}: \text { FISH: } \\
46, X Y 2^{\text {nd }}: \\
46, X X 2^{\text {nd }}: \\
\text { FISH: 46,XX }\end{array}$ & - & Live born \\
\hline $113^{32}$ & 17 & AMA & $\begin{array}{l}1^{\text {st }}: \\
46, X Y[14] / 47, X Y+8[1] \\
2^{\text {nd }}: 46, X Y\end{array}$ & $\begin{array}{l}\text { Blood: } \\
46, \mathrm{XY}[10] / 47, \mathrm{XY}\end{array}$ & $\begin{array}{l}\text { Preterm } \\
\text { \#\&[ike]ry }\end{array}$ \\
\hline $114^{33}$ & NA & ADV. RISK & $46, \mathrm{XY}[17] / 47, \mathrm{XY}+8[8]$ & $\begin{array}{l}\text { Blood culture: } \\
\text { 46,XY }[46] / 47, \mathrm{XY}- \\
\text { Blood } \\
\text { transformed: } \\
\text { 46,XY } \\
\text { Umbilical cord: } \\
46, \mathrm{XY}[43] / 47, \mathrm{XY}\end{array}$ & $\begin{array}{l}\text { Live born } \\
+8[54] \\
\\
+8[57]\end{array}$ \\
\hline
\end{tabular}




\begin{tabular}{|c|c|c|c|c|c|}
\hline Case & GA & Indication & $\begin{array}{l}\text { Amniotic } \\
\text { fluid }\end{array}$ & Tissue & Outcome \\
\hline $115^{11}$ & NA & NA & 46,XY[91]/47,XY B\$\$\$]d: 46,XY & $\begin{array}{l}\text { Umbi cord: } \\
\text { 46,XY } \\
\text { Amnion: } \\
\text { 46,XY Blood: } \\
\text { 46,XY } \\
\text { Placenta: } \\
\text { 46,XY }\end{array}$ & NA \\
\hline $116^{34}$ & 18 & AMA & $46, \mathrm{XY} / 47, \mathrm{XY}+8-$ & $\begin{array}{l}\text { Skin: } \\
46, \mathrm{XY} / 47, \mathrm{XY}+8 \\
\text { Other fetal } \\
\text { tissue: } 46, \mathrm{XY}\end{array}$ & TOP \\
\hline $117^{35}$ & 18 & US ABN & $\begin{array}{l}46, \mathrm{XX}[26] / 47, \mathrm{XX}+8[1] \\
\operatorname{arr} \\
8^{*} 2[\sim 90] / 8^{*} 3[\sim 10]\end{array}$ & - & TOP \\
\hline $118^{36}$ & NA & ADV. RISK & $46, \mathrm{XX} / 47, \mathrm{XX}+8-$ & - & NA \\
\hline $119^{37}$ & 24 & AMA & $\begin{array}{l}1^{\text {st }}: \quad \text { Blood: } 46, \mathrm{XY} \\
46, \mathrm{XY} / 47, \mathrm{XY}+8 \\
2^{\text {nd }}: 46, \mathrm{XY}\end{array}$ & - & Live born \\
\hline $120^{38}$ & NA & NA & $46, \mathrm{XN} / 47, \mathrm{XN}+8-$ & $46, \mathrm{XN}$ & TOP \\
\hline $121^{38}$ & NA & NA & $46, \mathrm{XN} / 47, \mathrm{XN}+8-$ & $46, \mathrm{XN} / 47, \mathrm{XN}+8$ & TOP \\
\hline $122^{38}$ & NA & NA & $46, \mathrm{XN} / 47, \mathrm{XN}+8-$ & $46, \mathrm{XN} / 47, \mathrm{XN}+8$ & TOP \\
\hline $123^{38}$ & NA & NA & $46, \mathrm{XN} / 47, \mathrm{XN}+8-$ & - & TOP \\
\hline $124^{38}$ & NA & NA & $46, \mathrm{XN} / 47, \mathrm{XN}+8-$ & $46, \mathrm{XN}$ & TOP \\
\hline $125^{39}$ & NA & NA & $46, \mathrm{XX}[23] / 47, \mathrm{XX}+8[77]$ & - & TOP \\
\hline $126^{39}$ & NA & NA & $46, \mathrm{XY}[42] / 47, \mathrm{XY}+8[4]$ & $46, \mathrm{XY} / 47, \mathrm{XY}+8$ & TOP \\
\hline $127^{39}$ & NA & AMA & $46, \mathrm{XY}[73] / 47, \mathrm{XY}+8[27]$ & $\begin{array}{l}\text { Kidney: } \\
\text { 46,XY Brain: } \\
\text { 46,XY } \\
\text { Placenta: } \\
\text { 46,XY[47]/47,XY }\end{array}$ & $\begin{array}{l}\text { TOP } \\
+8[3]\end{array}$ \\
\hline $128^{39}$ & NA & NA & $46, \mathrm{XY}[60] / 47, \mathrm{XY}+8[40]$ & $\begin{array}{l}\text { Skin: } \\
\text { 46,XY[70]/47,XY } \\
\text { Placenta: } \\
46, X Y[50] / 47, X Y\end{array}$ & $\begin{array}{l}\text { TOP } \\
+8[30] \\
+8[50]\end{array}$ \\
\hline $129^{39}$ & NA & NA & $46, \mathrm{XX}[13] / 47, \mathrm{XX}+8[87]$ & $46, \mathrm{XX} / 47, \mathrm{XX}+8$ & TOP \\
\hline $130^{39}$ & NA & AMA & $46, \mathrm{XY}[88] / 47, \mathrm{XY}+8[12]$ & $\begin{array}{l}\text { Umbi blood: } \\
\text { 46,XY Amnio: } \\
\text { 46,XY }\end{array}$ & Live born \\
\hline $131^{39}$ & NA & AMA & $46, \mathrm{XY}[56] / 47, \mathrm{XY}+8[2]$ & $\begin{array}{l}\text { Skin: } \\
46, \mathrm{XY}[4] / 47, \mathrm{XY}+\end{array}$ & $\begin{array}{r}\text { TOP } \\
+8[16]\end{array}$ \\
\hline $132^{39}$ & NA & AMA & $46, \mathrm{XX}[54] / 47, \mathrm{XX}+8[5]$ & - & TOP \\
\hline $133^{39}$ & NA & ADV. RISK & $46, \mathrm{XX}[50] / 47, \mathrm{XX}+8[2]$ & $\begin{array}{l}\text { Blood: } \\
46, \mathrm{XX}\end{array}$ & Live born \\
\hline $134^{39}$ & NA & AMA & $46, \mathrm{XY}[62] / 47, \mathrm{XY}+8[38]$ & $\begin{array}{l}\text { Blood: } \\
46, \mathrm{XY}[5] / 47, \mathrm{XY}+\end{array}$ & $\begin{array}{l}\text { TOP } \\
+8[5]\end{array}$ \\
\hline $135^{40}$ & 28 & NA & $46, \mathrm{XY}[56] / 47, \mathrm{XY}+8[6]$ & $\begin{array}{l}\text { Blood: } \\
46, \mathrm{XY}[21] / 47, \mathrm{XY}\end{array}$ & $\begin{array}{l}\text { Live born } \\
+8[29]\end{array}$ \\
\hline
\end{tabular}




\begin{tabular}{|c|c|c|c|c|c|}
\hline Case & GA & Indication & $\begin{array}{l}\text { Amniotic } \\
\text { fluid }\end{array}$ & Tissue & Outcome \\
\hline $136^{41}$ & NA & AMA & $\begin{array}{l}1^{\text {st }}: \quad \text { Blood: } 46, \mathrm{XY} \\
46, \mathrm{XY}[48] / 47, \mathrm{XY}+8[2] \\
2^{\text {nd }}: 46, \mathrm{XY}\end{array}$ & Blood: 46,XY & Live born \\
\hline $137^{42}$ & NA & NA & $46, \mathrm{XY}[37] / 47, \mathrm{XY}+8[3]$ & - & Live born \\
\hline $138^{42}$ & NA & NA & $46, \mathrm{XX}[28] / 47, \mathrm{XX}+8[2]$ & - & Live born \\
\hline $139^{43}$ & - & - & $46, \mathrm{XN} / 47, \mathrm{XN}+8-$ & $46, \mathrm{XN}$ & Live born \\
\hline $140^{43}$ & - & - & $46, \mathrm{XN} / 47, \mathrm{XN}+8-$ & $46, \mathrm{XN}$ & Live born \\
\hline $141^{43}$ & - & - & $46, \mathrm{XN} / 47, \mathrm{XN}+8-$ & - & Live born \\
\hline $142^{43}$ & - & - & $46, \mathrm{XN} / 47, \mathrm{XN}+8-$ & - & Live born \\
\hline $143^{43}$ & - & - & $46, \mathrm{XN} / 47, \mathrm{XN}+8-$ & - & Live born \\
\hline $144^{43}$ & - & - & $46, \mathrm{XN} / 47, \mathrm{XN}+8-$ & $46, \mathrm{XN}$ & Live born \\
\hline $145^{43}$ & - & - & $46, \mathrm{XN} / 47, \mathrm{XN}+8-$ & - & Live born \\
\hline $146^{44}$ & - & - & $46, \mathrm{XN} / 47, \mathrm{XN}+8-$ & $46, \mathrm{XN}$ & TOP \\
\hline
\end{tabular}

Table S1. Cases of trisomy 8 mosaicism detected on amniocentesis.

AMA: advanced maternal age (>35), NA : not available, ADV. RISK: advanced risk of chromosomal anomalies on prenatal screening, US ABN: abnormal findings on ultrasound, TOP: terminations of pregnancy, SAB: spontaneous abortion

*: No information whether it is fetal tissue or post-abortem/postnatal tissue.

\begin{tabular}{|c|c|c|c|c|c|c|c|}
\hline Case & GA & Indication & $\begin{array}{l}\text { Previous } \\
\text { CVS } \\
\text { normal? }\end{array}$ & $\begin{array}{l}\text { Previous } \\
\text { CVS } \\
\text { normal? }\end{array}$ & $\begin{array}{l}\text { Previous } \\
\text { amni- } \\
\text { otic } \\
\text { fluid } \\
\text { normal? }\end{array}$ & $\begin{array}{l}\text { Fetal } \\
\text { tissue }\end{array}$ & $\begin{array}{l}\text { Fetal } \\
\text { tissue }\end{array}$ \\
\hline & & & STC & LTC & & (prenatal) & (postnatal) \\
\hline \multicolumn{8}{|c|}{ DCCR } \\
\hline 147 & 24 & NA & - & - & - & \multicolumn{2}{|c|}{ 46,XY /47,XY $48, X Y / 47, X Y+\& ® P$} \\
\hline 148 & 13 & $\begin{array}{l}\text { Parent } \\
\text { with } \\
\text { chromo- } \\
\text { somal } \\
\text { abnormality }\end{array}$ & - & - & \multicolumn{3}{|c|}{ 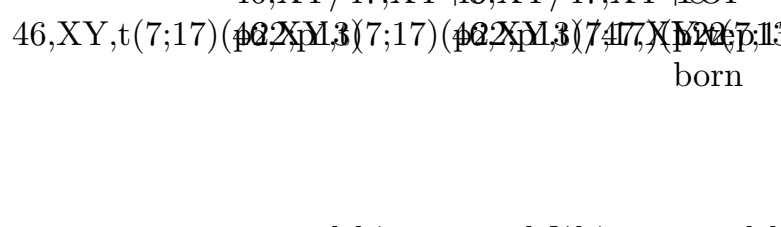 } \\
\hline 149 & 17 & $\begin{array}{l}\text { ADV. } \\
\text { RISK }\end{array}$ & - & - & $46, \mathrm{XY}$ & \multicolumn{2}{|c|}{ 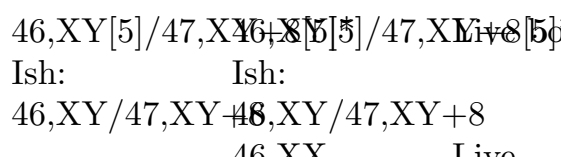 } \\
\hline 150 & 16 & NA & - & - & \multicolumn{2}{|l|}{$\begin{array}{l}46, X X \\
\operatorname{inv}(9)(p 13 q 21)\end{array}$} & $\begin{array}{ll}46, \mathrm{XX}, & \text { Live } \\
\operatorname{inv}(9)(\mathrm{p} 13 \mathrm{q} 21) \not b \phi \bar{\eta} \mathrm{XX}\end{array}$ \\
\hline 151 & 16 & AMA & - & - & \multicolumn{2}{|l|}{$46, \mathrm{XX}$} & $\begin{array}{r}46, \mathrm{XX} / 47, \mathrm{XX} \underset{ \pm \mathrm{ve}}{ } \\
\text { born }\end{array}$ \\
\hline \multicolumn{8}{|c|}{$\begin{array}{l}\text { Published } \\
\text { cases }\end{array}$} \\
\hline $152^{4}$ & NA & AMA & $46, \mathrm{XY}$ & - & - & - & $\begin{array}{lr}\text { Blood: } & \text { Live bc } \\
\text { 46,XY[38] } / 47, \mathrm{XY}+8[ \\
\text { Skin: } \\
46, \mathrm{XY}[47] / 47, \mathrm{XY}+8[\end{array}$ \\
\hline
\end{tabular}




\begin{tabular}{|c|c|c|c|c|c|c|c|}
\hline Case & GA & Indication & $\begin{array}{l}\text { Previous } \\
\text { CVS } \\
\text { normal? }\end{array}$ & $\begin{array}{l}\text { Previous } \\
\text { CVS } \\
\text { normal? }\end{array}$ & $\begin{array}{l}\text { Previous } \\
\text { amni- } \\
\text { otic } \\
\text { fluid } \\
\text { normal? }\end{array}$ & $\begin{array}{l}\text { Fetal } \\
\text { tissue }\end{array}$ & $\begin{array}{l}\text { Fetal } \\
\text { tissue }\end{array}$ \\
\hline $153^{4}$ & NA & $\begin{array}{l}\text { US } \\
\text { ABN }\end{array}$ & - & - & $\begin{array}{l}\text { FISH: } \\
46, \mathrm{XY}\end{array}$ & \multicolumn{2}{|c|}{$46, \mathrm{XY}[61] / 47, \mathrm{XY}+8[4]$} \\
\hline $154^{32}$ & 22 & AMA & - & - & $\begin{array}{l}46, \mathrm{XY} \\
\text { FISH: } 46, \\
\text { XY }\end{array}$ & - & $\begin{array}{l}\text { Blood: } 46, \quad \text { Pretern } \\
\text { XY[50]/47,XY ded[so] } \\
\text { Reexamina- } \\
\text { tion AM: } \\
46, \mathrm{XY}[45] / 47, \mathrm{XY}+8[\end{array}$ \\
\hline $155^{45}$ & 18 & $\begin{array}{l}\text { ADV. } \\
\text { RISK }\end{array}$ & - & - & $46, \mathrm{XY}$ & - & $\begin{array}{lr}\text { Blood: } & \text { Emerg } \\
46, \mathrm{XY}[75] / 47, \mathrm{XY}+8\end{array}$ \\
\hline $156^{46}$ & 20 & $\begin{array}{l}\text { ADV. } \\
\text { RISK }\end{array}$ & - & - & $46, \mathrm{XY}$ & - & $\begin{array}{l}\text { Blood: Pretern } \\
\text { 46,XX[13]/47,Xditef } \\
\text { Skin: } \\
46, \mathrm{XX}[5] / 47, \mathrm{XX}+8[1\end{array}$ \\
\hline $157^{47}$ & 18 & US ABN & $46, \mathrm{XY}$ & $47, \mathrm{XY}+8$ & - & - & $\begin{array}{l}\text { Fetal urine: TOP } \\
46, \mathrm{XY}[60] / 47, \mathrm{XY}+8[ \\
\text { Skin FISH: } \\
46, \mathrm{XY}[26] / 47, \mathrm{XY}+8[ \\
\text { FISH } \\
\text { muscle: } \\
46, \mathrm{XY}[46] / 47, \mathrm{XY}+8[ \\
\text { Cardiac } \\
\text { blood } \\
\text { FISH: } \\
46, \mathrm{XY} \\
\text { Renal } \\
\text { FISH: } \\
46, \mathrm{XY}[84] / 47, \mathrm{XY}+8[ \\
\text { Placenta: } \\
46, \mathrm{XY} / 47, \mathrm{XY}+8\end{array}$ \\
\hline $158^{48}$ & 23 & $\begin{array}{l}\mathrm{US} \\
\mathrm{ABN}\end{array}$ & - & - & - & $\begin{array}{l}\text { Blood: } \\
46, \mathrm{XY}\end{array}$ & $\begin{array}{ll}- & \text { Live } \\
\mathrm{XY}+8[8] & \text { born }\end{array}$ \\
\hline
\end{tabular}

Table S2. Cases of trisomy 8 mosaicism first detected in fetal tissue.

CVS: chorion villus sample, AMA: advanced maternal age (>35), NA : not available, ADV. RISK: advanced risk of chromosomal anomalies on prenatal screening, US ABN: abnormal findings on ultrasound, TOP: terminations of pregnancy.

*: No information whether it is fetal tissue or post-abortem/postnatal tissue. 


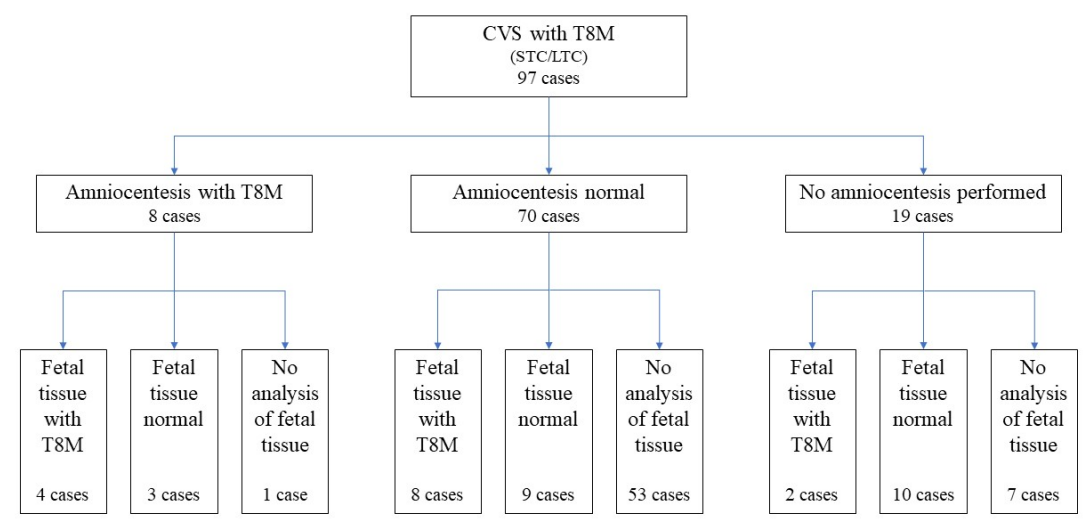

